\title{
MODIFIKASI PENGOLAHAN DURIAN FERMENTASI (TEMPOYAK) DAN PERBAIKAN KEMASAN UNTUK MEMPERTAHANKAN MUTU DAN MEMPERPANJANG UMUR SIMPAN
}

\section{PROCESS MODIFICATION AND PACKAGING IMPROVMENT OF FERMENTED DURIAN (TEMPOYAK) TO RETAIN QUALITY AND EXTENDSHELF LIFE}

\author{
Rapeka Reli, Endang Warsiki*, dan Mulyorini Rahayuningsih \\ Departemen Teknologi Industri Pertanian, Fakultas Teknologi Pertanian, Institut Pertanian Bogor, \\ Kampus IPB Darmaga, Jl. Raya Dramaga, Bogor, Indonesia \\ E-mail:endang.warsiki@gmail.com
}

Makalah: Diterima 28 Februari 2016; Diperbaiki 25 Oktober 2016; Disetujui 10 Nopember 2016

\begin{abstract}
Tempoyakis one of traditional food that has short shelf life. The pasteurization and packaging improvement could be expected can maintain the quality and extend the tempoyak's shelf life. This research used polyethylene terephtalate (PET) and polyamide as packaging materials; with modified atmosphere packaging (MAP), non MAP, vacuum and non vacuum. The parameters quality of tempoyak were observed by value of $\mathrm{pH}$, sugar content, lactic acid, alcohol, lactic acid bacteria growth and total plate count. The result showed that the best quality of tempoyak was produced by product with pasteurization treatment. Lactobacillus genus with L.plantarum, L. casei, and L. fermentum were the dominant species of lactic acid bacteria. The result also showed that after the tempoyak was fermented during 84 hours, then the pasteurization should be conducted to stop the fermentation. The $84^{\text {th }}$ hours was a constant phase in which that was the right time to inhibit the acid lactic bacteria growth. Pasteurized tempoyak packaged in PET with MAP technique had the longest shelf life as much as 84 days than others treatment whose had aboutonly 14 untill 56 days. The decreasing of tempoyak quality at 84 days was showed by colour change of tempoyak from yelowness to brown, $p H$ decreased from 3.97 to 3.73 , lactic acid content decreased from $1.49 \%$ to $0.99 \%$, sugar content decreased from $16.57 \%$ to $3.28 \%$, alcohol content of $0.32 \%$, number of lactic acid bacteria decreased from $174.3 \times 10^{4} \mathrm{cfu} / \mathrm{g}$ to $8.6 \times 10^{2} \mathrm{cfu} / \mathrm{g}$, and total plate count from $177 \times 10^{4} \mathrm{cfu} / \mathrm{g}$ to $182.3 \times 10^{3} \mathrm{cfu} / \mathrm{g}$.
\end{abstract}

Keywords: modified atmosfir packaging, pasteurization, tempoyak, vacuum

\section{ABSTRAK}

Tempoyak adalah salah satu makanan tradisional hasil fermentasi spontan buah durian oleh bantuan bakteri yang memiliki umur simpan pendek. Modifikasi pengolahan dan perbaikan kemasan diharapkan dapat mempertahankan mutu dan memperpanjang umur simpan. Jenis kemasan yang digunakan adalah polyetyleneterephtalate (PET) dan polyamide, dengan teknik pengemasan modified atmosfir packaging (MAP), nonmodified atmosfir packaging (MAP), vakum, dan non vakum. Parameter mutu tempoyak yang diamati adalah $\mathrm{pH}$, kadar gula, asam laktat, alkohol, pertumbuhan bakteri asam laktat dan total bakteri. Hasil menunjukkan bahwa mutu tempoyak terbaik diperoleh pada produk pasteurisasi. Hasil isolasi bakteri yang dominan adalah kelompok bakteri asam laktat genus Lactobacillus dengan spesies L. plantarum, L. Casei, dan L. fermentum. Hasil penelitian menunjukkan bahwa setelah tempoyak difermentasi selama 84 jam maka pasteurisasi harus dilakukan untuk memperlambat laju fermentasi. Pada jam ke-84 adalah fase pertumbuhan konstan yang merupakan waktu yang tepat untuk tempoyak dipasteurisasi. Tempoyak pasteurisasi dalam kemasan PET dengan teknik pengemasan MAP memiliki umur simpan lebih panjang yaitu 84 hari dibandingkan dengan 14 hingga 56 hari untuk tempoyak non pasteurisasi dalam kemasan PET dengan teknik pengemasan non MAP. Penurunan mutu tempoyak ditunjukkan dengan perubahan warna dari putih kekuningan menjadi coklat dengan nilai $\mathrm{pH}$ awal dari 3,97 turun menjadi 3,73, kadar asam laktat dari 1,49\% turun menjadi $0,99 \%$, kadar gula dari $16,57 \%$ turun menjadi 3,28\%, kandungan alkohol sebesar $0,32 \%$, jumlah bakteri asam laktat dari $174,30 \times 10^{4} \mathrm{Cfu} / \mathrm{g}$ turun menjadi 8,60x $10^{2} \mathrm{Cfu} / \mathrm{g}$, dan total jumlah bakteri dari $177,00 \times 10^{4} \mathrm{Cfu} / \mathrm{g}$ menjadi182,30x12 $\mathrm{Cfu} / \mathrm{g}$.

Kata kunci:modified atmosfir packaging, pasteurisasi, tempoyak, vakum

\section{PENDAHULUAN}

Durian merupakan jenis buah klimaterik yang dicirikan dengan produksi $\mathrm{CO}_{2}$ dan etilen yang cepat selama pematangan sehingga mudah mengalami kerusakan akibat perubahan kimia, aktifitas enzim dan mikroba (Yuliana, 2005). Oleh karena itu durian perlu diolah menjadi produk yang tahan simpan dan bernilai ekonomi tinggi seperti tempoyak. Tempoyak merupakan produk olahan daging buah durian yang melibatkan bakteri asam laktat (BAL) dengan penambahan sedikit garam yang dikenal dengan proses fermentasi spontan. Tempoyak dimanfaatkan sebagai bumbu masak oleh 
masyarakat khas melayu seperti Lampung, Jambi, Sumatera Selatan, Bengkulu, Kalimantan Barat, Sumatera Barat, dan Aceh. Amin et al.(2004) melaporkan bahwa penambahan kadar garam terbaik untuk tempoyak adalah sekitar 3\% (b/b). Fermentasi tempoyak secara spontan pada umumnya terjadi sekitar 4 hingga 7 hari (Leisner et al., 2001) dan daging durian berubah dari massa yang padat ke semisolid disertai dengan aroma asam yang kuat (Yuliana et al.,2011).

Hasil riset terdahulu (Leisner et al., 2001) menyatakan bahwa BAL yang terlibat di dalam tempoyak umumnya adalah bakteri yang bersifat heterofermentatif. Bakteri heterofermentatif adalah jenis bakteri yang selain penghasil asam-asam organik juga menghasilkan alkohol dan $\mathrm{CO}_{2}$. Minarni et al.(2013) menyatakan bahwa laju fermentasi yang terus berlangsung dengan cepat akan menghasilkan alkohol dengan hasil samping $\mathrm{CO}_{2}$. Kandungan alkohol yang tinggi tidak diinginkan pada tempoyak karena dapat merusak citrarasa. Selain faktor laju fermentasi yang cepat, faktor yang menyebabkan kerusakan dan kebusukan pada tempoyak adalah proses pengemasan yang kurang sesuai. Faktor-faktor tersebut dapat mempercepat terjadinya penurunan mutu tempoyak, yang secara fisik ditandai dengan(1) perubahan warna, (2) bau alkohol menyengat dan, (3) adanya serangga seperti belatung. Oleh karena itu diperlukan suatu usaha untuk mempertahankan mutu tempoyak dan memperpanjang umur simpan dengan cara menghambat atau memperlambat aktivitas mikroorganisme penghasil asam. Kandungan asam organik yang tinggi dihasilkan ketika bakteri asam laktat berada pada fase stasioner (Nur, 2005). Asam organik dapat menyebabkan terjadinya penurunan $\mathrm{pH}$. Nilai $\mathrm{pH}$ yang rendah dapat menghambat pertumbuhan bakteri patogen. Sampai saat ini penelitian tempoyak yang ada adalah identifikasi bakteri (Wirawati, 2002), identifikasi bakteri indigenous yang memfermentasi buah durian (Nurmailnda et al., 2013), penambahan garam (Amin et al., 2004), identifikasi asam organik (Nur, 2005), dan pengolahan tempoyak (Yuliana, 2007), tetapi penelitian tentang usaha memperpanjang umur simpan tempoyak belum dilakukan. Oleh karena itu, pada penelitian ini dilakukan upaya untuk mempertahankan mutu dan memperpanjang umur simpan.

Salah satu cara untuk meningkatkan umur simpan dan mempertahankan mutu tempoyak adalah modifikasi pengolahan tempoyak dengan pasteurisasi serta perbaikan kemasan. Pasteurisasi merupakan salah satu alternatif pengawetan suhu rendah yang tidak atau sedikit mengubah sifat fisikokimia bahan pangan, selain itu proses pasteurisasi dapat mematikan bakteri pembentuk spora serta inaktivasi enzim (Estiasih dan Ahmadi, 2011). Selain proses pengolahan, teknik pengemasan harus sesuai untuk tempoyak. Teknik pengemasan vakum dan modified atmosfir packaging (MAP) merupakan alternatif yang baik, karena dapat menyebabkan laju respirasi oleh bakteri menurun, mengurangi pertumbuhan mikroba, mengurangi kerusakan oleh enzim, memberikan efek visual yang baik bagi produk, dan memperpanjang umur simpan produk (Julianti dan Nurminah, 2006; Putu, 2011). Berdasarkan uraian diatas, maka tujuan dari penelitian ini adalah : (i) memperoleh waktu pasteurisasi yang tepat untuk menghambat pertumbuhan bakteri asam laktat, (ii) mengidentifikasi jenis BAL dalam proses fermentasi durian, (iii) mendapatkan modifikasi cara pengolahan, jenis dan teknik pengemasan yang sesuai untuk memperpanjang umur simpan tempoyak.

\section{BAHAN DAN METODE}

\section{Bahan dan Alat}

Bahan yang digunakan adalah durian lokal yang diperoleh dari Parung Bogor, media Man Rogosa Shape (MRS) agar, $\mathrm{Na}_{2} \mathrm{SO}_{4}, \mathrm{H}_{2} \mathrm{SO}_{4}$, fenolftalein, $\mathrm{KI}$, sodium tiosulfat, $\mathrm{Pb}$-asetat, $\left(\mathrm{NH}_{4}\right)_{2}$ $\mathrm{HPO}_{4}$, larutan luff, $\mathrm{NaOH}, \mathrm{PCA}$, dan bahan kimia analisis lainnya. Jenis bahan pengemasan yang digunakan adalah plastik polyetyleneterephtalate (PET) dan polyamide. Peralatan yang digunakan adalah $\mathrm{pH}$ meter, gas analyzer $\mathrm{CO}_{2}$ dan $\mathrm{O}_{2}$, Gas Kromatografi Shimadzu (GC-17A), refrigerator, mikroskop, vakum packer (model lapack 550/s), dan peralatan analisis lainnya.

\section{Metode}

\section{Karakteristik Buah Durian}

Buah durian yang masak disortasi dan dikupas untuk mendapatkan daging durian kualitas baik. Durian kualitas baik akan menentukan mutu tempoyak. Buah durian yang digunakan berwarna putih hingga kuning. Proses selanjutnya daging durian dipisahkan dari bijinya, bagian biji dikumpulkan sebagai limbah dan daging buah digunakan untuk proses berikutnya dan dilakukan uji komposisi kimianya yaitu kadar air, serat, abu, protein, lemak, dan karbohidrat (AOAC, 2005).

\section{Pembuatan Tempoyak}

Metode yang digunakan dalam penelitian ini adalah fermentasi secara spontan. Daging buah durian kualitas baik selanjutnya ditimbang, kemudian ditaburi garam $3 \%(\mathrm{~b} / \mathrm{b})$ dan gula $1 \%(\mathrm{~b} / \mathrm{b})$ secara berlapis hingga homogen, selanjutnya difermentasi dalam wadah jenis plastik PET dan diinkubasi pada suhu ruang.

\section{Pembuatan Kurva Pertumbuhan Bakteri Asam Laktat (BAL) \\ Kurva pertumbuhan BAL ditujukan untuk penentuan titik pasteurisasi yang tepat ketika pertumbuhan BAL berada pada fase stasioner. Uji ini dilakukan dengan cara menginokulasikan kultur}


dari tempoyak hasil fermentasi pada media MRS dan diinkubasikan selama 24 jam pada suhu $37^{\circ} \mathrm{C}$. Pengamatan dilakukan pada jam ke-0 dan setiap 12 jam. Jumlah total bakteri dihitung dengan persamaan 1 (Lindayani dan Hartayanie, 2013).

\section{Pasteurisasi Tempoyak}

Tempoyak dipasteurisasi pada suhu $65^{\circ} \mathrm{C}$ selama 30 menit pada saat bakteri pembentuk tempoyak berada pada fase stasioner. Fase stasioner didapatkan dari hasil kurva pertumbuhan mikroba. Tempoyak hasil fermentasi sebelum dan sesudah pasteurisasi diuji mutunya, tempoyak segera dikemas dan disimpan.

\section{Identifikasi Jenis Bakteri Asam Laktat (BAL)}

Penentuan BAL dilakukan dengan cara menginokulasikan kultur dari tempoyak hasil fermentasipada media MRS dan diinkubasikan selama 48 jam pada suhu $37^{\circ} \mathrm{C}$. Perhitungan koloni yang tumbuh dilakukan setelah 48 jam. Koloni yang membentuk zona bening diidentifikasi sebagai bakteri asam laktat. Setiap koloni yang terbentuk diamati dan diidentifikasi secara morfologi, dan jumlah koloni dihitung dengan persamaan 1 .

\section{Pengujian Mutu Tempoyak Sebelum dan Sesudah Pasteurisasi}

Variabel mutu yang diamati adalah kadar gula total (SNI 01-2892-1992), kadar asam laktat (AOAC, 2000), pH (SNI06-6989.11-2004), TPC(SNI 01-2332.3-2006) dan jumlah bakteri asam laktat (Lindayani dan Hartayanie, 2013). Pengujian mutu untuk melihat mutu awal tempoyak.

\section{Pengemasan Tempoyak}

Kemasan yang digunakan adalah plastik polyethyleneterephthalate (PET) dan polyamide. Plastik jenis polyamide yang sudah diisi tempoyak dilakukan pengemasan dengan teknikvakum dan non vakum, sedangkan plastik PET dikemas dengan teknik MAP dan non MAP. Teknik MAP dilakukan dengan menginjeksikan gas $\mathrm{CO}_{2}$ kedalam kemasan sebanyak $67 \%$ hingga $69 \%$ dan $\mathrm{O}_{2}$ sebanyak 5\% hingga $6 \%$. Selanjutnya hasil pengemasan disimpan pada suhu ruang. Kode sampel dari semua perlakuan. Disajikan pada Tabel 1.

\section{Pengujian Mutu Tempoyak dalam Kemasan \\ Uji mutu meliputi pengukuran kadar} gulatotal (SNI 01-2892-1992), kadar asam laktat (AOAC, 2000), pH (SNI06-6989.11-2004), TPC (SNI 01-2332.3-2006), jumlah bakteri asam laktat (Lindayani dan Hartayanie, 2013) dan alkohol (SNI 3565-2009). Pengujian dilakukan setiap dua hari selama dua minggu, dan dilanjutkan satu minggu sekali selama dua minggu, dan selanjutnya tiga minggu sekali sampai tempoyak rusak.

\section{Rancangan Percobaan}

Rancangan percobaan yang digunakan adalah Rancangan Acak Lengkap (RAL) faktorial dengan dua faktor yaitu modifikasi cara pengolahan (faktor pertama) dan jenis kemasan dengan teknik pengemasan (faktor kedua). Faktor pertama terdiri dari dua taraf yaitu pasteurisasi dan non pasteurisasi, sedangkan faktor kedua terdiri dari empat tarafyaitu jenis kemasan PET dengan teknik pengemasan MAP, jenis kemasan PET dengan teknik pengemasan non MAP, jenis kemasan polyamide dengan teknik pengemasan vakum, dan jenis kemasan polyamide dengan teknik pengemasan non vakum.Penelitian dilakukan sebanyaktiga kali ulangan. Analisa data menggunakan analisis ragam (ANOVA) dengan taraf signifikansi 5\%. Apabila terdapat perbedaan antar perlakuanmaka dilanjutkan Uji Duncan.Model rancangan percobaan secara umum dapat dilihat pada persamaan 2 (Walpole, 2005).

Total bakteri $(\mathrm{cfu} / \mathrm{gr})=$ Jumlah koloni per cawan $\times \frac{1}{\text { faktor pengenceran }}$

Tabel 1. Kode sampel dari semua perlakuan

\begin{tabular}{ll}
$\begin{array}{c}\text { Kode } \\
\text { sampel }\end{array}$ & \multicolumn{1}{c}{ Arti kode } \\
\hline PPM & Tempoyak pasteurisasi, jenis kemasan PET, dan teknik pengemasan MAP \\
PPNM & Tempoyak pasteurisasi, jenis kemasan PET, dan teknik pengemasan non MAP \\
PNV & Tempoyak pasteurisasi, jenis kemasan polyamide, dan teknik pengemasan vakum \\
PNNV & Tempoyak pasteurisasi, jenis kemasan polyamide, dan teknik pengemasan non vakum \\
NPM & Tempoyak non pasteurisasi, jenis kemasan PET, dan teknik pengemasan MAP \\
NPNM & Tempoyak non pasteurisasi, jenis kemasan PET dan teknik pengemasan MAP \\
NNV & Tempoyak non pasteurisasi, jenis kemasan polyamide, dan teknik pengemasan vakum \\
NNNV & Tempoyak non pasteurisasi, jenis kemasan polyamide, dan teknik pengemasan non vakum \\
\hline
\end{tabular}

$Y_{i j k}=\mu+A_{i}+B_{j}+(A B)_{i j}+\varepsilon_{i j k}$ dimana: 


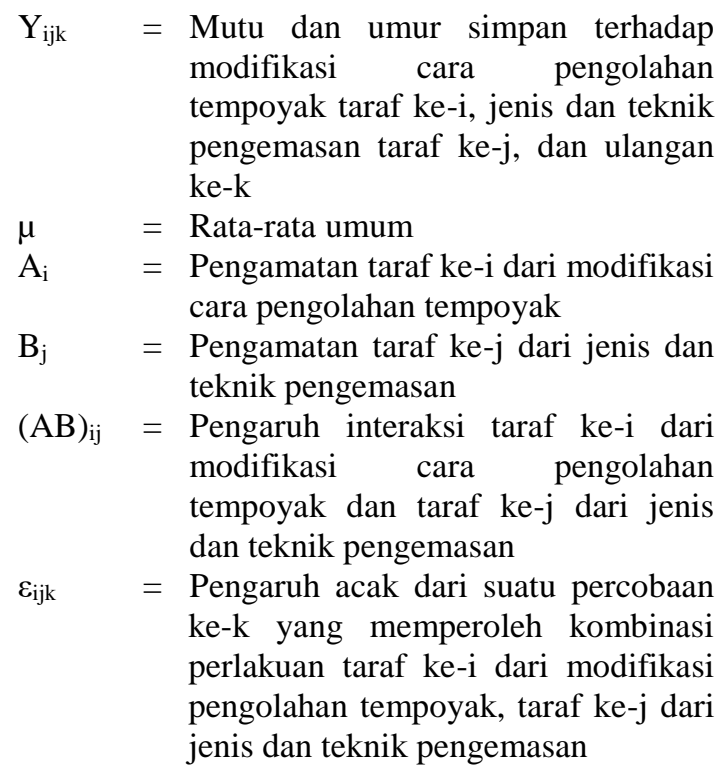

\section{HASIL DAN PEMBAHASAN}

\section{Karakteristik Buah Durian (Duriozibethinus Murr.)}

Analisis proksimat bertujuan untuk mengetahui karakteristik bahan sebagai informasi awal sebelum dilakukan pembuatan tempoyak. Buckle et al. (2010) menyatakan bahwa nutrisi seperti karbohidrat, vitamin, nitrogen, lemak dan mineral merupakan senyawa yang dibutuhkan BAL untuk tumbuh dan memperbanyak sel, sementara air digunakan sebagai media untuk pertumbuhan BAL.

Tabel 2 menunjukkan bahwa hasil analisis proksimat buah durian dari penelitian ini dan penelitian Haryanto dan Royaningsih (2003) tidak berbeda jauh. Tabel 2 dapat dilihat bahwa kandungan karbohidrat pada buah durian cukup tinggi dibandingkan dengan kandungan gizi lainnya seperti protein, lemak. Karbohidrat berfungsi sebagai sumber energi bagi bakteri asam laktat. Yuliana (2005) melaporkan bahwa buah durian mengandung cukup karbohidrat untuk dihidrolisis menjadi gula pada proses fermentasi durian. Perbandingan kandungan gizi durian dari hasil penelitian terdahulu dan penelitian ini dapat dilihat pada Tabel 2.

Kandungan karbohidrat seperti gula-gula sederhana yang ada dalam buah durian mendukung kehidupan mikroflora alami pemfermentasi (khamir dan bakteri) untuk menjadi asam. Mikroorganisme tersebutlah yang memicu terjadinya fermentasi spontan. Lebih lanjut Puspawati et al. (2010) melaporkan bahwa pertumbuhan bakteri asam laktat dapat terus berlangsung apabila karbohidrat, asam amino dan nutrien lainnya tersedia. Selama proses fermentasi, karbohidrat dihidrolisis menjadi gula dan akan diuraikan menjadi senyawa yang sederhana seperti, asam laktat, asam asetat, asam propionat dan etil alkohol oleh bakteri asam laktat. Keberadaan senyawa-senyawa yang diproduksi oleh bakteri asam laktat tersebut dapat menyebabkan citra rasa pada tempoyak dan dapat berfungsi sebagai pengawet (Yuliana, 2005). Selain itu tersedianya protein dan zat gizi lain dalam buah durian dapat menyokong pertumbuhan mikroflora-mikroflora terutama bakteri asam laktat yang memerlukan sejumlah kecil protein dalam pertumbuhannya.

\section{Kurva Pertumbuhan BAL}

Kurva pertumbuhan adalah suatu informasi mengenai fase hidup suatu bakteri yang pada umumnya meliputi fase adaptasi, log (pertumbuhan eksponensial), stasioner, dan kematian. Kurva pertumbuhan digunakan untuk mengetahui kecepatan pertumbuhan sel dan pengaruh lingkungan terhadap kecepatan pertumbuhan (Altiok, 2004). Pembuatan kurva pertumbuhan merupakan bagian yang penting dari penelitian ini karena dapat menggambarkan hubungan waktu dan jumlah bakteri sehingga dapat diketahui lama fermentasi yang dibutuhkan untuk mendapatkan titik pasteurisasi tempoyak.

Gambar 1 menunjukkan fase stasioner berada pada waktu ke 72 hingga 84 jam. Fase stasioner BAL dari hasil penelitian terdahulu seperti pada tempoyak berdasarkan pengukuran nilai optical density adalah 18 hingga 30 jam (Yuliana, 2008) dan perhitungan berdasarkan jumlah bakteri adalah 48 hingga 144 jam (Amin et al., 2004), pada susu kambing dan tapai singkong adalah 18 hingga 54 jam (Adnan dan Tan, 2006). Fase stasioner BAL tidak bisa selalu sama karena tergantung pada media dan jenis BAL (Yuliana, 2007). Fase stasioner BAL merupakan fase dimana jumlah asam organik dihasilkan dalam jumlah yang berlebih (Yuliana, 2005).

Tabel 2. Hasil analisis komposisi buah durian bobot basah

\begin{tabular}{lcc}
\hline Parameter & Hasil analisa $(\%)$ & $\begin{array}{c}\text { Penelitian terdahulu } \\
\text { (Haryanto dan Royaningsih, 2003) }\end{array}$ \\
\hline Kadar air & 64,57 & 65,50 \\
Kadar abu & 1,74 & 1,50 \\
Kadar protein & 2,08 & 3,14 \\
Kadar serat & 6,01 & 6,31 \\
Kadar lemak & 2,26 & 3,83 \\
Karbohidrat by difference & 23,33 & 22,27 \\
\hline
\end{tabular}




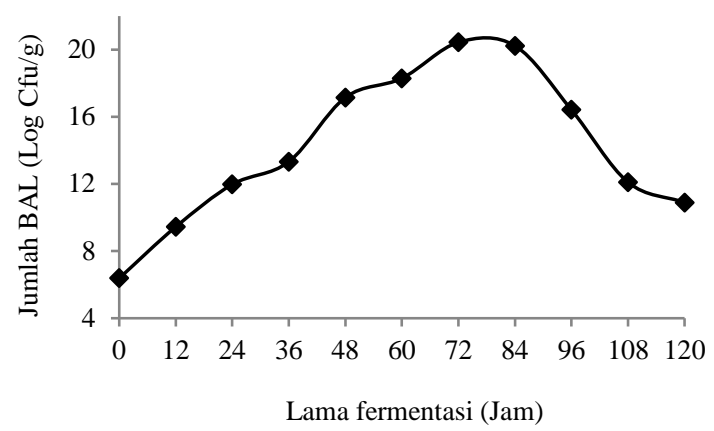

Gambar 1. Kurva pertumbuhan bakteri asam laktat selama proses fermentasi durian

Setelah mengalami fase stasioner, selanjutnya bakteri akan mengalami fase kematian, dan pada fase ini, sel yang mati menjadi lebih banyak dari pada terbentuknya sel-sel yang baru. Jika pada fase ini dibiarkan maka produk fermentasi akan mengalami kerusakan seperti perubahan warna, alkohol menyengat, terdapat kapang atau belatung. Oleh karena itu, pada fase stasioner tempoyak harus segera dipasteurisasi, dengan tujuan untuk membunuh mikroorganisme yang terlibat dalam proses fermentasi tempoyak sehingga laju fermentasi bisa diperlambat atau bahkan berhenti. Laju fermentasi yang lambat pada tempoyak dapat mencegah kerusakan produk lebih cepat, sehingga umur simpan bisa lebih panjang.

\section{Derajat Asam (pH)}

Pengukuran terhadap $\mathrm{pH}$ merupakan parameter yang menunjukkan pengaruh pertumbuhan dan pembentukan produk fermentasi. Bakteri membutuhkan pH optimum untuk tumbuh optimal. Pengaruh $\mathrm{pH}$ terhadap pertumbuhan bakteri berkaitan dengan aktivitas enzim. Enzim dibutuhkan oleh bakteri untuk mengkatalis reaksi-reaksi yang berhubungan dengan pertumbuhan bakteri. Apabila $\mathrm{pH}$ dalam suatu medium tidak sesuai, maka akan mengganggu kerja dari enzim-enzim tersebut dan dapat mempengaruhi pertumbuhannya. Hasil analisis ragam menunjukkan bahwa modifikasi pengolahan tempoyak berpengaruh sangat nyata terhadap $\mathrm{pH}$, sedangkan jenis dan teknik pengemasan antar perlakuan tidak berbeda nyata terhadap nilai $\mathrm{pH}$. Tempoyak yang direpresentasikan dengan nilai $\mathrm{pH}$ terhadap lama waktu penyimpanan dapat dilihat pada Gambar 2.

Gambar 2 menunjukkan nilai $\mathrm{pH}$ tempoyak selama penyimpanan terus mengalami penurunan. Laju penurunan $\mathrm{pH}$ diduga adanya sejumlah besar asam laktat yang dihasilkan oleh BAL sehingga $\mathrm{pH}$ media menjadi asam. Pernyataan tersebut didukung oleh hasil penelitian Amin et al. (2004) melaporkan bahwa tempoyak dengan jumlah BAL awal sebesar $\log 7,45 \mathrm{cfu} / \mathrm{gr}$ dan meningkat menjadi $\log 10,10$ cfu/gr, dihasilkan nilai $\mathrm{pH}$ awal dari 6,62 turun menjadi 3,96 dengan kadar asam laktat awal 0,71\% meningkat menjadi $2,80 \%$. Nilai $\mathrm{pH}$ tempoyak pasteurisasi lebih tinggi dibandingkan dengan tempoyak non pasteurisasi.

Pada tempoyak pasteurisasi jumlah BAL berkurang saat proses pemanasan berlangsung sehingga jumlah BAL penghasil asam lebih sedikit dibandingkan dengan tempoyak non pasteurisasi, yang mengakibatkan nilai $\mathrm{pH}$ tempoyak pasteurisasi lebih tinggi dari pada non pasteurisasi. Nilai $\mathrm{pH}$ tempoyak pasteurisasi pada awal penyimpanan 3,97 dan turun menjadi 3,67 dengan rata-rata 3,87. Sementara nilai $\mathrm{pH}$ tempoyak non pasteurisasi pada awal penyimpanan bernilai 4 dan terus mengalami penurunan sampai 3,23 dengan rata-rata 3,48. Nilai $\mathrm{pH}$ tersebut masih merupakan $\mathrm{pH}$ yang baik untuk pertumbuhan BAL, sehingga masih dimungkinkan BAL masih terus tumbuh selama penyimpanan. Selain itu, Dinas Kesehatan menyatakan tempoyak yang masih baik memiliki nilai $\mathrm{pH}$ diatas 3 dengan batas maksimal $\mathrm{pH}$ sebesar 6,50. Jika $\mathrm{pH}$ tempoyak bernilai diatas 6,50 artinya masih tergolong durian segar belum jadi tempoyak dan jika $\mathrm{pH}$ bernilai dibawah 3,00 tempoyak sudah rusak karena BAL mengalami lisis.

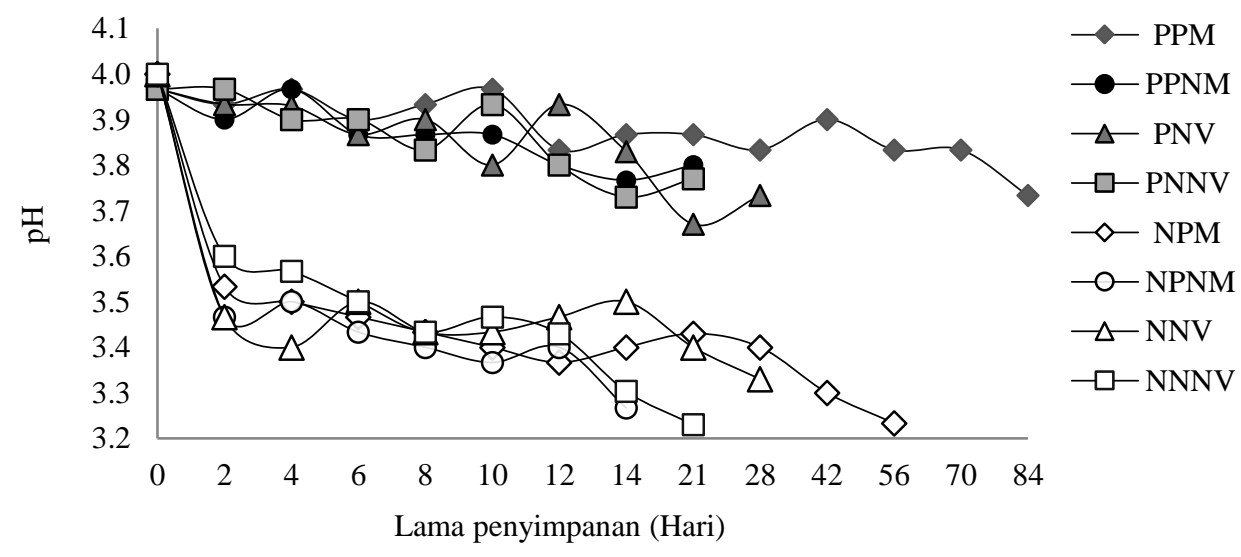

Gambar 2. Nilai pH tempoyak pasteurisasi dan non pasteurisasi terhadap lama waktu penyimpanan dari berbagai perlakuan 
Adanya BAL dalam tempoyak mengindikasikan bahwa kualitas tempoyak masih baik. Nur (2005) melaporkan bahwa pH yang optimum bagi aktivitas bakteri asam laktat berkisar 3,00 sampai 8,00. Produk fermentasi yang memiliki nilai $\mathrm{pH}$ rendah relatif lebih tahan selama penyimpanan dibandingkan dengan makanan yang mempunyai nilai $\mathrm{pH}$ netral atau mendekati netral. Nilai $\mathrm{pH}$ rendah tidak dapat ditumbuhi oleh bakteri patogen dan pembusuk. Umumnya mikroba patogen dan pembusuk dapat tumbuh antara $\mathrm{pH}$ 6,00 hingga 8,00 (Buckle et al., 2010). Semakin cepat BAL mampu menurunkan $\mathrm{pH}$ pada makanan fermentasi, maka semakin cepat penghambatan terhadap kebusukan produk sehingga umur simpan bisa lebih panjang. Namun, batas $\mathrm{pH}$ paling rendah untuk tempoyak dengan nilai 3,00. Nilai $\mathrm{pH}$ 1,00 atau 2,00 dalam tempoyak tidak dikehendaki, dikarenakan pada nilai tersebut dinding sel BAL terganggu dan mengalami lisis ketika kondisi lingkungan sangat asam, sehingga pertumbuhannya terhambat bahkan tidak dapat tumbuh pada kondisi tersebut (Guerra et al., 2006).

\section{Total Gula}

Gula digunakan oleh BAL sebagai nutrien untuk pertumbuhan. Hasil analisis ragam menunjukkan bahwa modifikasi pengolahan berpengaruh nyata terhadap kadar gula. Hasil uji Duncan menunjukkan bahwa tempoyak pasteurisasi berbeda nyata dengan tempoyak non pasteurisasi. Hal ini dikarenakan tempoyak pasteurisasi menghasilkan jumlah BAL lebih sedikit sehingga kebutuhan untuk memanfaatkan gula sebagai sumber energi lebih sedikit dibandingkan tempoyak non pasteurisasi dengan jumlah BAL lebih banyak (Gambar 5). Hasil analisis ragam dari jenis kemasan dan teknik pengemasan antar perlakuan tidak berbeda nyata. Tempoyak yang direpresentasikan dengan kadar gula terhadap lama waktu penyimpanan dapat dilihat pada Gambar 3.

Gambar 3 menunjukkan bahwa selama proses penyimpanan nilai kadar gula produk mengalami penurunan. Kadar gula tempoyak pasteurisasi pada awal penyimpanan adalah $16,57 \%$ dan turun menjadi $3,28 \%$ dengan rata-rata $10,41 \%$. Kadar gula pada tempoyak non pasteurisasi pada awal penyimpanan adalah $16,79 \%$ dan turun menjadi $2,67 \%$ dengan rata-rata $9,11 \%$. Laju penurunan kadar gula tempoyak non pasteurisasi lebih cepat dari pada tempoyak pasteurisasi. Laju penurunan kadar gula tempoyak disebabkan oleh adanya reaksi biokimia selama proses fermentasi, yang menghidrolisis gula menjadi asam. Pada tempoyak non pasteurisasi jumlah BAL lebih banyak dari pada tempoyak pasteurisasi (Gambar 5), sehingga kemampuan BAL mengkonversi gula menjadi senyawa-senyawa sederhana (seperti asam laktat) lebih banyak. Salsabila et al. (2013) melaporkan bahwa fermentasi merupakan proses perubahan kimia yang disebabkan oleh aktivitas mikroorganisme untuk memperoleh energi dengan memecah gula untuk pertumbuhan dan metabolisme dari mikroorganisme tersebut. Hidrolisis gula akan menghasilkan asam piruvat, yang selanjutnya ditransformasi menjadi asam organik, $\mathrm{CO}_{2}$, dan asetaldehid. Asetaldehid akan diubah menjadi etanol melalui enzim alkohol dehidrogenase.

\section{Asam Laktat}

Kadar asam laktat merupakan salah satu indikator kualitas kimia produk tempoyak. Asam laktat digunakan sebagai acidulants (bahan pengasam) yang dapat menurunkan $\mathrm{pH}$, sehingga pertumbuhan bakteri patogenakan terhambat. Hasil analisis ragam menunjukkan bahwa modifikasi pengolahan berpengaruh sangat nyata terhadap kadar asam laktat. Uji lanjut Duncan menunjukkan bahwa tempoyak non pasteurisasi berbeda nyata dengan tempoyak pasteurisasi. Selanjutnya, hasil analisis ragam darijenis kemasan dan teknik pengemasan berpengaruh sangat nyata terhadap kadar asam laktat. Uji Duncan menunjukkan bahwa tempoyak yang dikemas dengan teknik pengemasan MAP dan vakum berbeda nyata dengan tempoyak yang dilakukan pengemasan dengan teknik non MAP dan non vacum.

Kadar asam laktat tempoyak pasteurisasi pada awal penyimpanan diperoleh $1,49 \%$ dan turun menjadi $0,99 \%$ dengan rata-rata $1,43 \%$. Kadar asam laktat tempoyak non pasteurisasi pada awal penyimpanan diperoleh $1,53 \%$ dan turun menjadi $1,09 \%$ dengan rata-rata $1,81 \%$. Surono (2004) menyatakan bahwa asam laktat pada produk fermentasi dihasilkan ketika terjadi proses metabolisme BAL yang memiliki enzim aldolase dan fosfoketolase. Aldolase akan memfermentasi heksosa menjadi asam laktat secara homofermentatif, sedangkan fosfoketolase merubah pentosa dan glukonat menjadi asam laktat secara heterofermentatif. Asam laktat yang dihasilkan oleh BAL akan disekresikan keluar sel dan terakumulasi di dalam substrat sehingga meningkatkan keasaman produk. Namun demikian, proses metabolisme ini akan terhenti atau terhambat akibat produk fermentasi tersebut diproses pasteurisasi atau dipanaskan, seperti diketahui sel BAL merupakan molekul-molekul besar yang merupakan protein. Protein tidak tahan panas dan akan terdenaturasi. Selain itu proses pemanasan akan menginaktifkan enzim. Akibatnya, proses produksi asam laktat akan terhenti karena metabolisme tidak berjalan (Chotimah, 2009), sehingga menyebabkan total asam tempoyak pasteurisasi lebih rendah dari tempoyak non pasteurisasi. Hasil pengamatan kadar asam laktat dari semua perlakuan dapat dilihat pada Gambar 4. 


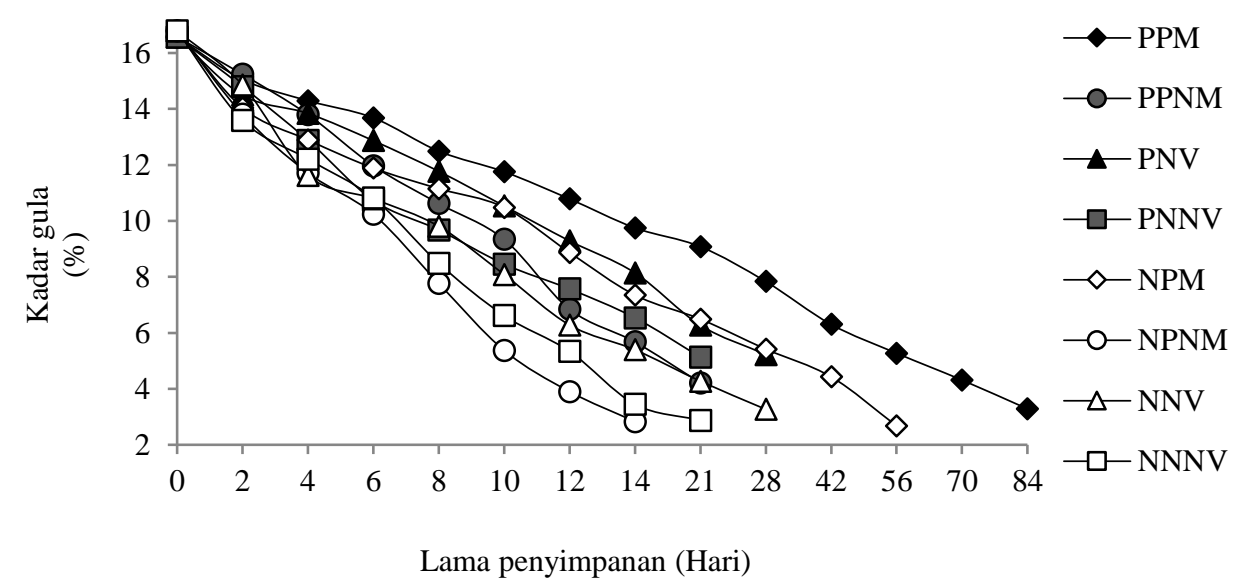

Gambar 3. Kadar gula tempoyak pasteurisasi dan non pasteurisasi dari berbagai perlakuan terhadap lama penyimpanan

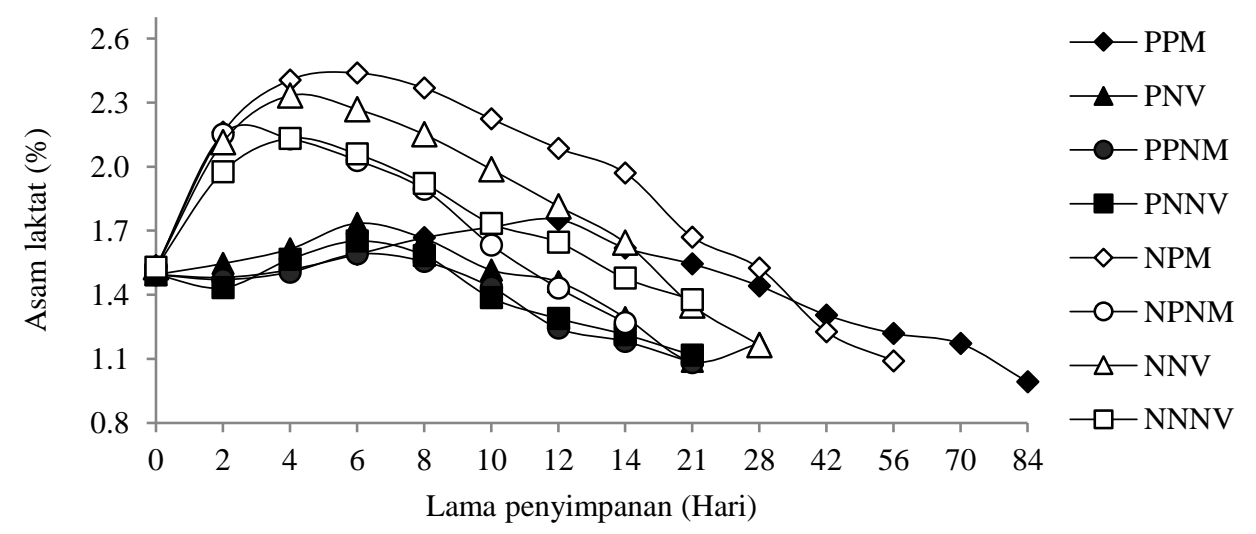

Gambar 4. Kadar asam laktat tempoyak pasteurisasi dan non pasteurisasi dari berbagai perlakuan terhadap lama penyimpanan

Pada Gambar 4 menunjukkan bahwa tempoyak yang dikemas dengan teknik pengemasan vakum (anaerob) dan MAP (anaerob fakultatif) diperoleh kadar asam laktat lebih tinggi dibandingkan dengan perlakuan lainnya.Asam laktat adalah metabolit utama dari fermentasi BAL, yang dihasilkan dari oksidasi piruvat dan memproduksi asam untuk regenerasi NAD+ dari NADH yang dibentuk selama tahap glikolisis.Tahap glikolisis sel, tidak memerlukan oksigen untuk pertumbuhan sehingga produksi asam laktat dapat terjadi secara optimal. Namun demikian, bukan berarti dalam kondisi aerob atau ketika keberadaan oksigen cukup, BAL tidak mampu melakukan respirasi metabolisme. Pada kondisi ini, keberadaan oksigen akan mempengaruhi proses fermentasi menjadi terbatas. Kondisi aerob akan menghasilkan asam laktat lebih rendah dari pada kondisi anaerob (Serrazanetti et al., 2013), sehingga dapat dimengerti jika kemudian vakum akan mengasilkan laktat lebih tinggi dibandingkan kemasan MAP. Lebih lanjut, jumlah asam laktat yang tinggi dapat merupakan racun bagi pertumbuhan bakteri yang menyebabkan produk cepat mengalami kebusukan. Hal ini sejalan dengan pernyataan Yuliana (2005), bahwa tempoyak yang baik memiliki kadar asam laktat masih berada dalam konsentrasi yang tinggi. Penyimpanan yang terlalu lama dapat mempengaruhi keasaman tempoyak. Jika kadar keasaman dari asam laktat selama penyimpanan terus mengalami penurunan artinya mutu tempoyak mulai mengalami penurunan. Selain itu, perlakuan NNV merupakan tempoyak yang dikemas dengan plastik polyamide. Jenis plastik polyamide merupakan permeabilitas yang baik terhadap gas dan aroma, tahan gesekan, benturan, tarikan, stabil terhadap perubahan suhu (Sampurno, 2006). Sifat yang demikian diduga dapat melindungi tempoyak dari pertukaran gas dari luar dan dalam kemasan. Selain itu Mujiarto (2005) melaporkan bahwa plastik polyamide merupakan jenis kemasan yang paling bagus untuk teknik pengemasan vacum.

Kadar asam laktat dalam tempoyak menentukan kualitas produk. Kandungan asam yang tinggi dapat menurunkan pH. Nilai pH untuk pengemasan vakum pada perlakuan PNV rata-rata 3,86 dan perlakuan NNV rata-rata 3,49. Nilai $\mathrm{pH}$ pada teknik pengemasan MAP untuk perlakuan PPM 
rata-rata sebesar 3,88 dan NPM rata-rata sebesar 3,46 . Nilai $\mathrm{pH}$ sebesar itu, masih tergolong kedalam pangan berasam tinggi. Golongan pangan berasam tinggi umumnya memiliki umur simpan lebih panjang. Namun demikian, dalam kondisi anaerob, gula cendrung dirubah menjadi alkohol, dan jika ini dibiarkan maka produk mengalami kerusakan.

\section{Bakteri Asam Laktat (BAL) dan Jumlah Bakteri}

Jumlah mikroba dalam suatu bahan pangan merupakan salah satu indikator kualitas mikrobiologis suatu produk. Jumlah mikroba dalam bahan pangan mempengaruhi cepat lambatnya kerusakan bahan pangan tersebut. Pada produk fermentasi umumnya melibatkan BAL (Wirawati, 2002). Keberadaan BAL sangat penting dalam tempoyak. Kualitas tempoyak dipengaruhi pada reaksi biokimia selama fermentasi. BAL mengekskresikan enzim ekstraseluler pemecah karbohidrat dan menghasilkan gula sederhana seperti disakarida yang dapat dimanfaatkan untuk metabolisme dan menghasilkan asam. Pada proses fermentasi tempoyak, BAL mempunyai peranan sebagai (1) mengasamkan produk dengan memproduksi asam laktat dan, (2) menghasilkan antimikroba berupa asam organik disebut bakteriosin. Asam laktat dan senyawa-senyawa hasil fermentasi yang dihasilkan oleh BAL dapat memberikan aroma dan rasa pada tempoyak. BAL tidak berbahaya dikonsumsi, akan tetapi dapat menurunkan kualitas tempoyak jika jumlahnya berlebih karena dapat mempercepat laju fermentasi. Jumlah BAL yang berlebih dapat mengakibatkan populasi BAL tidak seimbang dengan nutrisi yang tersedia, sehingga terjadi kompetisi nutrisi dan BAL akan cepat mati yang mengakibatkan terjadi penumpukkan metabolit. Hal ini dapat menyebabkan kerusakan dan kebusukkan pada tempoyak dan terbentuk alkohol. Oleh karena itu, ketersediaan BAL dalam tempoyak harus dikontrol.

Pasteurisasi merupakan cara yang memungkinkan untuk mengurangi jumlah BAL yang berlebih pada tempoyak, sehingga laju fermentasi dapat diperlambat. Selain itu, salah satu cara mengontrol agar BAL tumbuh lebih lambat adalah dengan mempertahankan lingkungan dalam kemasan berada pada kondisi anaerob fakultatif. Apabila media lingkungan dalam kemasan pada kondisi aerob maka akan menyebabkan laju respirasi semakin cepat, seperti terlihat pada Gambar 5 perlakuan PPNM, PNNV, NPNM, dan NNNV pada lama penyimpanan berkisar 21 hari jumlah $\mathrm{BAL}$ menunjukkan penurunan tajam. Selanjutnya, apabila media lingkungan pada kondisi anaerob dapat menyebabkan pertumbuhan bakteri terhambat. Seperti yang terlihat pada Gambar 5, perlakuan PNV dan NNV telah menghasilkan jumlah BAL yang rendah. Ketersediaan konsentrasi oksigen di dalam kemasan vakum lebih rendah daripada perlakuan lainnya, yang mengakibatkan pertumbuhan mikroba menjadi lebih lambat. Putu (2011) melaporkan bahwa dalam kondisi vakum mikroorganisme akan mati dengan sendirinya akibat habisnya oksigen dan meningkatnya konsentrasi $\mathrm{CO}_{2}$ yang dihasilkan selama metabolisme. Namun BAL merupakan bakteri anaerob fakultatif yang artinya dapat bertahan hidup dengan baik jika ada sedikit oksigen. Gambar 5 dapat dilihat pada perlakuan PPM dan NPM dengan menggunakan teknik pengemasan MAP, laju penuruan jumlah BAL lebih lambat dari perlakuan lainnya. Kondisi anaerob fakultatif dapat dicapai dengan pengaturan kemasan, yaitu dengan cara menekan jumlah oksigen dengan menginjeksikan $\mathrm{CO}_{2}$ yang disebut dengan pengemasan teknik MAP. Rendahnya konsentrasi $\mathrm{O}_{2}$ dan tingginya $\mathrm{CO}_{2}$ dapat memperpanjang umur simpan produk. Namun demikian keberadaan $\mathrm{O}_{2}$ harus dikontrol dengan baik, karena jika $\mathrm{O}_{2}$ dibawah batas minimal maka akan terjadi respirasi anaerob yang dapat menghasilkan alkohol. Jika hal ini dibiarkan akibatnya dapat menyebabkan kerusakan produk. Muhdarsyah (2007) melaporkan bahwa teknik MAP yang baik untuk penyimpanan produk segar terolah adalah pada konsentrasi oksigen kurang dari 10\%, karena dapat menghambat terjadinya browning dan pertumbuhan mikroba.

Perlakuan PPM dan NPM merupakan tempoyak yang dikemas dengan plastik PET. Plastik PET merupakan jenis kemasan yang memiliki permeabilitas terhadap gas,uap air, dan aroma yang rendah, tahan terhadap benturan, gesekan dan kekuatan sobek (Sampurno, 2006). Sifat yang demikian dapat dimungkinkan jika produk yang dikemas memiliki umur simpan lebih panjang. Salah satu faktor yang menyebabkan produk pangan cepat mengalami kerusakan adalah oksigen. Jika pertukaran gas dari dalam dan luar kemasan tinggi dapat menyebabkan laju respirasi yang cepat, terjadinya browning. Hal demikian dapat memicu kerusakan dan kebusukan pada produk pangan.

Laju penurunan jumlah BAL yang lambat pada perlakuan PPM dan NPM (Gambar 5), diikuti dengan laju penurunan kadar asam laktatyang lambat pada perlakuan yang sama (Gambar 4). Konsentrasi oksigen yang digunakan pada penelitian ini sebesar $5 \%$ sampai $6 \%$. Kandungan oksigen sebesar itu memungkinan BAL penghasil asam bertahan hidup lebih lama, sehingga dapat terus memproduksi asam laktat dengan laju yang lebih rendah. Akumulasi asam yang dihasilkan tersebut dapat menyebabkan media lingkungan menjadi asam sehingga terjadi penurunan $\mathrm{pH}$. Pada Gambar 2 dapat dilihat Nilai $\mathrm{pH}$ tempoyak cukup rendah yaitu sekitar 4 hingga 3 . Nilai pH sebesar itu dapat menghambat pertumbuhan bakteri patogen dan pembusuk, sehingga umur simpan tempoyak bisa lebih panjang.

Hasil analisis ragam menunjukkan bahwa modifikasi pengolahan berpengaruh sangat nyata terhadap BAL dan TPC. Uji lanjut duncan menunjukkan bahwa tempoyak non pasteurisasi 
berbeda nyata dengan tempoyak pasteurisasi. Selanjutnya, hasil analisis ragam dari jenis kemasan dan teknik pengemasan berpengaruh sangat nyata terhadap BAL dan TPC. Uji lanjut Duncan menunjukkan bahwa tempoyak yang dikemas dengan teknik pengemasan vakum berbeda nyata dengan perlakuan lainnya.

Oksigen merupakan nutrisi kunci untuk mikroba anaerob, biasanya ditemukan sebagai penyusun air selular dan komponen organik. Mikroba yang mendapatkan energi dari proses metabolisme, membutuhkan oksigen sebagai final oksigen atau elektron acceptor. Metabolisme yang menggunakan glukosa sebagai subtratnya membutuhkan oksigen lebih banyak. Ketersediaan oksigen dalam proses fermentasi yang menggunakan glukosa sebagai substrat lebih terbatas karena terus digunakan secara cepat untuk proses metabolisme. Sehingga dapat dipahami jika dalam kondisi vakum jumlah bakteri lebih sedikit, dikarenakan ketersediaan oksigen tidak mencukupi sehingga proses metabolisme terganggu. Gambar 5 menyajikan BAL dan total bakteri (Gambar 6) pada semua perlakuan.

Gambar 5 menunjukkan bahwa jumlah BAL pada tempoyak pasteurisasi selama penyimpanan meningkat sesaat, kemudian terjadi penurunan. Peningkatan ini terjadi karena kadar gula (nutrien) yang tersedia (Gambar 3) memungkinkan untuk mencukupi kebutuhan jumlah populasi BAL (Gambar 5). Gambar 3 dapat dilihat bahwa kadar gula tempoyak pasteurisasi masih cukup tinggi yang artinya pada saat proses pemanasan tidak merusak kandungan gizi tempoyak. Kandungan gula tersebut digunakan oleh BAL sebagai nutrisi atau sumber energi. Hampir semua BAL hanya memperoleh energi dari metabolisme gula sehingga habitat pertumbuhannya hanya terbatas pada lingkungan yang menyediakan cukup gula atau bisa disebut dengan lingkungan yang kaya nutrisi (Chotimah, 2009). Namun demikian, jika kadar gula mulai habis maka akan menyebabkan penurunan jumlah BAL.
Berbeda dengan tempoyak non pasteurisasi, jumlah BAL pada awal penyimpanan cukup tinggi, demikian juga dengan kadar gula (Gambar 3), sehingga dapat menyebabkan terjadinya kompetisi nutrisi. Persaingan nutrisi dapat menyebabkan penurunan BAL karena jumlah sel yang mati lebih banyak dari pada sel hidup. Hasil identifikasi BAL pada penelitian ini ditemukan Lactobacillusspesies dari L. plantarum, L. casei. dan L. fermentum. Tabel 3 disajikan spesies dari Genus Lactobaciluus hasil dari penelitian

Gambar 5 menunjukkan bahwa jumlah BAL pada tempoyak pasteurisasi selama penyimpanan meningkat sesaat, kemudian terjadi penurunan. Peningkatan ini terjadi karena kadar gula (nutrien) yang tersedia (Gambar 3) memungkinkan untuk mencukupi kebutuhan jumlah populasi BAL (Gambar 5). Gambar 3 dapat dilihat bahwa kadar gula tempoyak pasteurisasi masih cukup tinggi yang artinya pada saat proses pemanasan tidak merusak kandungan gizi tempoyak. Kandungan gula tersebut digunakan oleh BAL sebagai nutrisi atau sumber energi. Hampir semua BAL hanya memperoleh energi dari metabolisme gula sehingga habitat pertumbuhannya hanya terbatas pada lingkungan yang menyediakan cukup gula atau bisa disebut dengan lingkungan yang kaya nutrisi (Chotimah, 2009). Namun demikian, jika kadar gula mulai habis maka akan menyebabkan penurunan jumlah BAL. Berbeda dengan tempoyak non pasteurisasi, jumlah BAL pada awal penyimpanan cukup tinggi, demikian juga dengan kadar gula (Gambar 3), sehingga dapat menyebabkan terjadinya kompetisi nutrisi. Persaingan nutrisi dapat menyebabkan penurunan BAL karena jumlah sel yang mati lebih banyak dari pada sel hidup. Hasil identifikasi BAL pada penelitian ini ditemukan Lactobacillus spesies dari L. plantarum, L. casei. dan L. fermentum. Tabel 3 disajikan spesies dari Genus Lactobaciluus hasil dari penelitian.

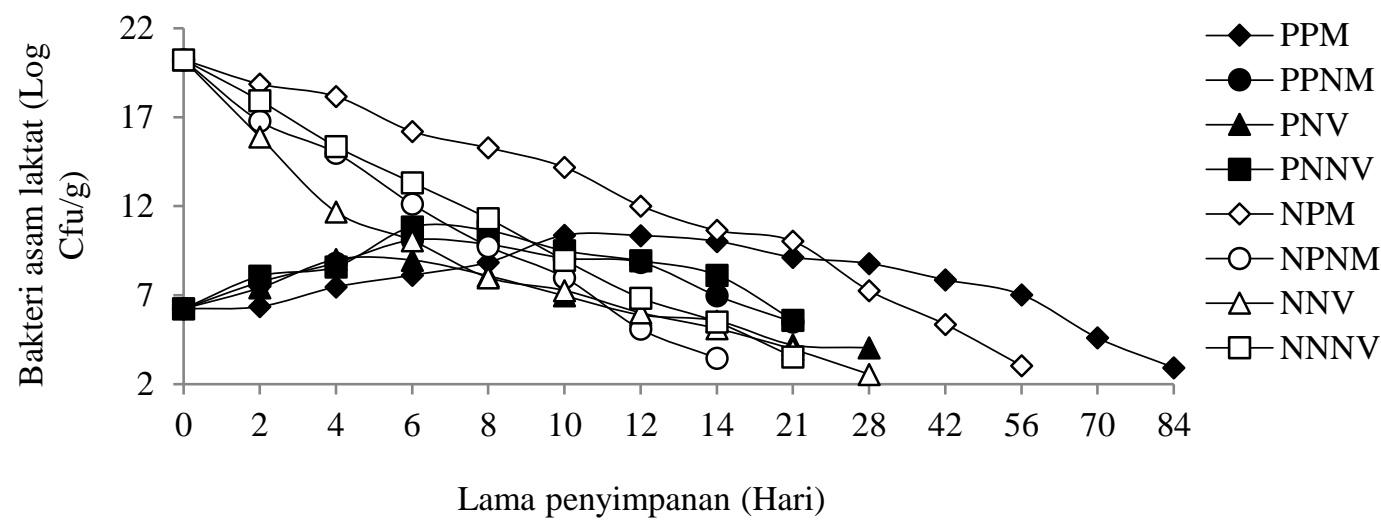

Gambar 5. Jumlah BAL tempoyak pasteurisasi dan non pasteurisasi dari berbagai perlakuan terhadap lama penyimpanan 


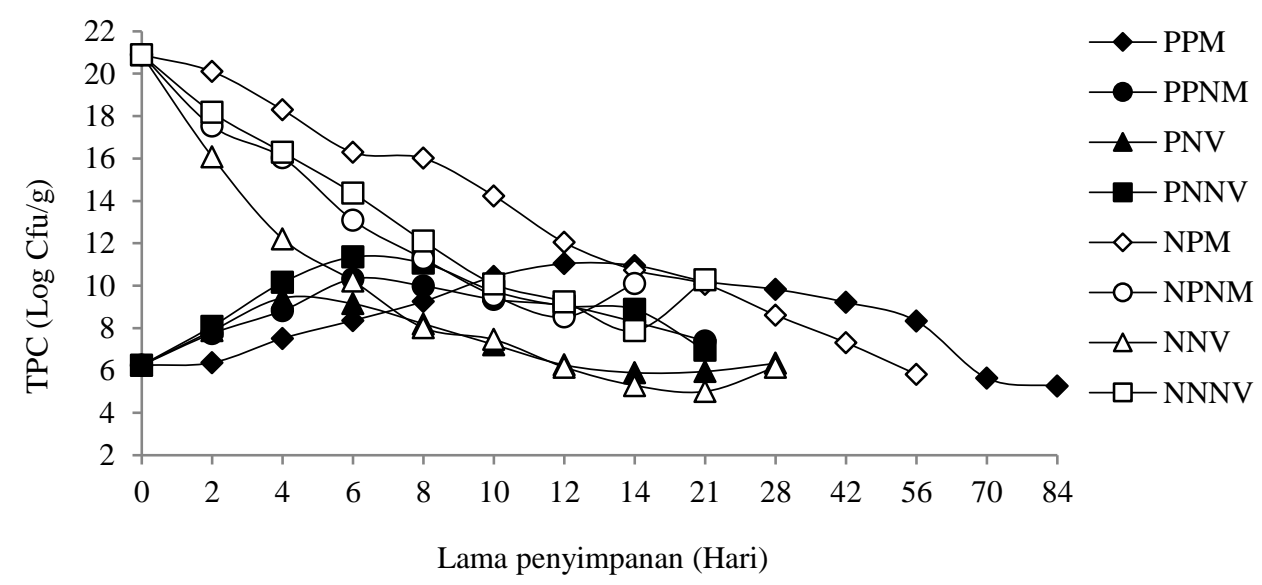

Gambar 6. Total jumlah bakteri tempoyak pasteurisasi dan non pasteurisasi dari berbagai perlakuan terhadap lama penyimpanan

Tabel 3. Spesies bakteri asam laktat dari genus Lactobacillus pada tempoyak pasteurisasi dan non pasteurisasi

\begin{tabular}{llcccc}
\hline \multicolumn{1}{c}{ Jenis bakteri } & Morfologi & Pewarnaan gas & Produksi gas & Katalase & Spora \\
\hline L. plantarum & Batang & + & heterofermentatif & - & - \\
L. fermentum & Batang & + & heterofermentatif & - & - \\
L. casei & Batang & + & heterofermentatif & - & - \\
\hline
\end{tabular}

Sedangkan nilai total bakteri (Gambar 6) mengikuti nilai dari jumlah BAL (Gambar 5), apabila total bakteri lebih tinggi artinya ada mikroorganisme lain. Hal ini dikarenakan pada saat inokulasi media yang digunakan untuk total bakteri merupakan media umum yang bisa ditumbuhi oleh semua bakteri, seperti BAL. Hasil identifikasi total bakteri dalam tempoyak ditemukan adanya bakteri Staphylococcus aureus, kapang Aspergillus niger, dan khamir Candida parapsilosis. Keberadaan Staphylococcus aureus tersebut dapat memproduksi enterotoksin yang membahayakan kesehatan konsumen jika mengkonsumsi tempoyak.

\section{Kandungan Alkohol}

BAL yang dihasilkan dalam penelitian ini adalah jenis bakteri yang bersifat heterofermentatif. Bakteri heterofermentatif mempunyai kemampuan untuk menghasilkan alkohol. Selain itu pada penelitian ini ditemukan khamir yang dapat memproduksi alkohol. Hasanah et al. (2012) melaporkan bahwa khamir mempunyai enzim yang berperan pada proses fermentasi senyawa gula, seperti memecah glukosa menjadi etanol dan $\mathrm{CO}_{2}$.

Tabel 3 menunjukkan bahwa tempoyak pasteurisasi menghasilkan kadar alkohol lebih rendah dari pada tempoyak non pasteurisasi. Hal ini dikarenakan pada tempoyak non pasteurisasi jumlah BAL lebih banyak dan ditemukan juga khamir, sehingga kemampuan menghasilkan alkohol menjadi lebih besar. Kadar alkohol yang diperoleh pada tempoyak pasteurisasi dari berbagai perlakuan kemasan kurang dari 0,5\%. Kandungan kurang dari $0,5 \%$ diharapkan dalam tempoyak, karena kandungan alkohol yang tinggi dapat mempengaruhi rasa yang tidak enak pada tempoyak.

Tabel 3 menunjukkan terdapat kandungan metanol pada tempoyak. Metanol merupakan senyawa kimia yang sangat beracun jika dikonsumsi manusia. Metanol diperoleh dari bahan hasil pertanian yang mengandung karbohidrat dengan cara fermentasi. Tempoyak merupakan makanan yang terbuat dari bahan pangan yang mengandung karbohidrat cukup tinggi dan difermentasi, sehingga dapat dimungkinkan jika tempoyak dapat menghasilkan metanol. Tempoyak yang rusak atau busuk dapat menghasilkan $\mathrm{CO}_{2}$ dan $\mathrm{CH}_{4}$, yang selanjutnya akan dikonversi menjadi gas sintesis $\left(\mathrm{CO}, \mathrm{CO}_{2}, \mathrm{H}_{2}\right)$ dengan bantuan katalis. Proses tersebut akan menghasilkan metanol.

Peningkatan produksi alkohol diikuti dengan penurunan nilai $\mathrm{pH}$. Hal ini dapat dilihat selama penyimpanan tempoyak non pasteurisasi menghasilkan kandungan alkohol lebih tinggi dengan nilai $\mathrm{pH}$ lebih rendah, sedangkan tempoyak pasteurisasi menghasilkan kandungan alkohol lebih rendah dengan nilai pH lebih tinggi (Gambar 2). Tingginya kandungan alkohol pada tempoyak non pasteurisasi dikarenakan jumlah BAL lebih banyak (Gambar 5) yang memiliki kemampuan menghasilkan alkohol lebih besar. Altiok (2004) melaporkan bahwa bakteri asam laktat mempunyai peranan esensial hampir dalam semua proses fermentasi produk yaitu untuk mengasamkan produk dengan memproduksi sebagian besar asam laktat (bakteri homofermentatif), asam asetat, etanol dan $\mathrm{CO}_{2}$ (bakteri heterofermentatif). 
Tabel 3. Hasil analisis kandungan alkohol pada tempoyak pasteurisasi dan non pasteurisasi dari variasi perlakuan

\begin{tabular}{cccc}
\hline $\begin{array}{c}\text { Waktu Pengamatan } \\
\text { (Hari) }\end{array}$ & Kode sampel & \multicolumn{2}{c}{ Hasil Analisis Alkohol $(\%)$} \\
\cline { 3 - 4 } 31 & NPNM & Metanol & Etanol \\
21 & NNNV & 0,03 & 3,93 \\
21 & PNNV & 0,04 & 1,1 \\
21 & PPNM & n.d & 0,35 \\
28 & NNV & n.d & 0,41 \\
28 & PNV & n.d & 0,52 \\
56 & NPM & 0,004 & 0,23 \\
84 & PPM & n.d & 0,61 \\
\hline
\end{tabular}

\section{KESIMPULAN DAN SARAN}

\section{Kesimpulan}

Hasil penelitian dapat disimpulkan bahwa waktu pasteurisasi yang tepat pada jam ke 84 Bakteri asam laktat yang teridentifikasi pada tempoyak adalah $L$. plantarum, $L$. casei. dan $L$. fermentum. Pasteurisasi dapat memperpanjang umur simpan sampai 84 hari dibandingkan dengan 14 hari untuk tempoyak tanpa pasteurisasi. Jenis kemasan baik PET maupun poliamyde tidak berpengaruh nyata terhadap umur simpan produk, sedangkan teknik pengemasan modified atmosfir packaging memberikan perlindungan yang lebih baik dibandingkan dengan vakum. Tempoyak pasteurisasi dengan kemasan PET dan teknik modified atmosfir packaging adalah produk yang terbaik. Produk ini mengalami perubahan mutu meliputi nilai $\mathrm{pH}$ awal dari 3,97 menjadi 3,73, kadar asam laktat dari 1,49\% menjadi $0,99 \%$, kadar gula dari $16,57 \%$ menjadi $3,28 \%$, kandungan alkohol sebesar $0,32 \%$, jumlah bakteri asam laktat dari $174,3 \times 10^{4} \mathrm{Cfu} / \mathrm{g}$ menjadi $8,6 \times 10^{2} \mathrm{Cfu} / \mathrm{g}$ dan total jumlah bakteri dari $177 \times 10^{4}$ Cfu/gmenjadi $182,3 \times 12^{3} \mathrm{Cfu} / \mathrm{g}$.

\section{Saran}

Diperlukan kajian lanjut tentang mekanisme dan model matematika laju penghambatan fermentasi tempoyak akibat proses pasteurisasi dan aplikasi kemasan MAP. Selain itu diperlukan kajian untuk menemukan teknik lain dalam usaha memperpanjang umur simpan tempoyak dalam kemasan seperti penggunaan kemasan aktif pelepas antimikroba atau agen lain yang dapat menghambat pertumbuhan BAL.

\section{DAFTAR PUSTAKA}

Adnan AFM dan Tan IKP. 2006. Isolation of lactic acid bacteria from Malaysian foods and assessment of the isolates for industrial potential. Int J BiolTechnol. 98: 1380-1385.

Altiok D. 2004. Kinetic modelling of lactic acid productionfrom whey [Disertasi]. Turkey: Izmir Institute of Technology.
Amin MA, Jaafar Z, dan Khim L. 2004. Effect of salt on tempoyak fermentation and sensory evaluation. AsianJ Biol Sci. 4 (5): 650-653.

AOAC.2000. Official Methods of Analysis of The Association of Analytical Chemists. Washington DC : AOAC.

AOAC. 2005. Official Methods of Analysis of The Association of Analytical Chemists. Washington DC : AOAC.

Buckle KA, Edwards RA, Fleet GH, Wootton M. 2010. Ilmu Pangan. Jakarta: UI-Press.

[BSN] Badan Standarisasi Nasional. 1992. Uji makanan dan minuman. SNI No. 01-28921992. Jakarta: BSN

[BSN] Badan Standarisasi Nasional. 2004. Cara uji derajat keasaman $(\mathrm{pH})$ dengan menggunakan alat $\mathrm{pH}$ meter-bagian 11 air dan air limbah. SNI No. 06-6989.11-2004. Jakarta : BSN.

[BSN] Badan Standarisasi Nasional. 2006. Cara uji mikrobiologi-bagian 3: penentuan angka lempeng total (ALT) pada produk perikanan. SNI No. 01-2332.3-2006. Jakarta : BSN.

[BSN] Badan Standarisasi Nasional. 2009. Etanol nabati. SNI No. 3565-2009. Jakarta: BSN.

Chotimah SC. 2009. Peranan Streptococcus thermophillus dan Lactobacillus bulgaricus dalam proses pembuatan yogurt. J Sci Pet. 4 (2): 47-52.

Estiasih T dan Ahmadi. 2011. Teknologi Pengolahan Pangan. Jakarta: Bumi Aksara.

Guerra NP, Bernardez PF, Mendez J, Cachaldora P, Castro LP. 2006. Production of four potentially probiotic lactic acid bacteria and their evaluation as feed additives for weaned piglets. J Anim Feed Sci Technol. 134: 89-107.

Haryanto B dan Royaningsih S. 2003. Hubungan antara ketuaan durian cv sunan dengan sifat fisiknya. J Agritech. 23 (1): 33-36.

Hasanah H, Jannah A, dan Fasya AG. 2012. Pengaruh lama fermentasi terhadap kadar alkoholtape singkong (Manihot utilissima pohl). J Alchemy. 2(1):68-79. 
Julianti E dan Nurminah M. 2006. Teknologi Pengemasan. Sumatera Utara: USU.

Leisner JJ, Vancanneyt M, Rusul G, Pot B, Lefebvre K, Fresi A, Tee LK. 2001. Identification of latic acid bacteria constituting the predominating microflora in an acidfermented condiment (tempoyak) popular in Malaysia. Int J Food Microbiol. 63: 149157.

Lindayani dan Hartayanie H. 2013. The maping of lactic acid bacteria from fermentation of local foods (Semarang: tempoyak, mandai and yellow bamboo shoot pickels. Proceedings of Indonesian Society Conference 2013 - International Conference on Society Lactic Acid Bacteria. Yogyakarta, Indonesia. 25-26 Januari 2013.

Minarni N, Ismuyanto B, dan Sutrisno. 2013. Pembuatan bioetanol dengan bantuan saccharomyces cerevisiae dari glukosa hasil hidrolisis biji durian (Durio zhibetinus Murr.). J Kim Indo. 1(1): 36-42.

Muhdarsyah. 2007. Kajian penyimpanan rajangan wortel segar terolah minimal dalam kemasan atmosfer termodifikasi [Tesis]. Bogor: Institut Pertanian Bogor.

Mujiarto I. 2005. Sifat dan Karakteristik Material Plastik dan Bahan Aditif. Semarang (ID): AMNI.

Nurmalinda A, Periadnadi, dan Nurmiati. 2013. Isolasi dan karakterisasi parsial bakteri indigenous pemfermentasi dari buah durian (Durio zibethinus Murr.). J Bio Indo. 2(1): 8-13.

Nur HS. 2005. Pembentukan asam organik oleh isolat bakteri asam laktat pada media ekstrak daging buah durian (Durio Zibethinus Murr.).J Bioscientiae. 2(1): 1524.

Puspawati NN, Nuraida L, dan Adawiyah DR. 2010. Penggunaan berbagai jenis bahan pelindung untuk mempertahankan viabilitas bakteri asam laktat yang diisolasi dari air susu ibu pada proses pengeringan beku. J Tek Ind Pert. 21(1) : 59-65.

Putu I. 2011. Karakteristik daging sapi dikemas dalam kantong plastik hampa udara (vakum pack). J Sci Pet. 11(2): 15-19.

Salsabila U, Mardiana D, dan Indahyanti E. 2013. Kinetika reaksi fermentasi glukosa hasil hidrolisa pati biji durian menjadi etanol. $J$ Kim Indo. 2 (1): 331-337.

Serrazanetti DI, Gottardi D, Montanari C, Gianotti A. 2013. Dynamic Stresses of Lactic Acid Bacteria Associated to Fermentation Processes. In Tech. 23: 6-7.

Sampurno RB. 2006. Aplikasi polimer dalam industri kemasan. J Sains Indo. 15-22.

Surono IS. 2004. Probiotik Susu Fermentasi dan Kesehatan. Jakarta : Tri Cipta Karya.

Walpole RE. 2005. Pengantar Statistik. Jakarta : Gramedia Pustaka Utama.

Wirawati CU. 2002. Potensi bakteri asam laktat yang diisolasi dari tempoyak sebagai probiotik [Thesis]. Bogor: Institut Pertanian Bogor.

Yuliana N. 2005. Identifikasi bakteri bukan penghasil asam laktat yang berasosiasi dengan tempoyak (fermented durian). $J$ Microbiol. 10 (1): 25-28.

Yuliana N. 2007. Pengolahan durian (Durio zibethinus) fermentasi (tempoyak). J Tek Ind Pert. 12 (2): 70-80.

Yuliana N. 2008. Kinetika pertumbuhan bakteri asam laktat isolat T5 yang berasal dari tempoyak. J Tek Ind Pert. 13 (2) : 108-116.

Yuliana N, Erlinda ID, dan Virgilio VG. 2011. The effect of spontaneous fermentation on the volatile flavor constituents of durian. Int $J$ Food Res. 18: 635-641. 